\title{
Front Matter: Volume 6679
}

, "Front Matter: Volume 6679," Proc. SPIE 6679, Remote Sensing and Modeling of Ecosystems for Sustainability IV, 667901 (22 October 2007); doi: 10.1117/12.778394

SPIE Event: Optical Engineering + Applications, 2007, San Diego, California, United SPIE. States 


\section{PROCEEDINGS OF SPIE}

\section{Remote Sensing and Modeling of Ecosystems for Sustainability IV}

Wei Gao

Susan L. Ustin

Editors

28-29 August 2007

San Diego, California, USA

Sponsored and Published by

SPIE

Cooperating Organizations

UV-B Monitoring and Research Program of U.S. Department of Agriculture (USA)

Natural Resource Ecology Laboratory, Colorado State University (USA)

Center for Spatial Technologies and Remote Sensing, International Center for Desert Affairs-

Research for Sustainable Development in Arid and Semi-Arid Lands (China)

PKU-CSU Joint Laboratory for Remote Sensing of Ecological Environments (China)

Volume 6679

Proceedings of SPIE, 0277-786X, v. 6679

SPIE is an international society advancing an interdisciplinary approach to the science and application of light. 
The papers included in this volume were part of the technical conference cited on the cover and title page. Papers were selected and subject to review by the editors and conference program committee. Some conference presentations may not be available for publication. The papers published in these proceedings reflect the work and thoughts of the authors and are published herein as submitted. The publisher is not responsible for the validity of the information or for any outcomes resulting from reliance thereon.

Please use the following format to cite material from this book:

Author(s), "Title of Paper," in Remote Sensing and Modeling of Ecosystems for Sustainability IV, edited by Wei Gao, Susan L. Ustin, Proceedings of SPIE Vol. 6679 (SPIE, Bellingham, WA, 2007) Article CID Number.

ISSN 0277-786X

ISBN 9780819468277

Published by

SPIE

P.O. Box 10, Bellingham, Washington $98227-0010$ USA

Telephone +1 3606763290 (Pacific Time) · Fax +1 3606471445

SPIE.org

Copyright (c) 2007, Society of Photo-Optical Instrumentation Engineers

Copying of material in this book for internal or personal use, or for the internal or personal use of specific clients, beyond the fair use provisions granted by the U.S. Copyright Law is authorized by SPIE subject to payment of copying fees. The Transactional Reporting Service base fee for this volume is $\$ 18.00$ per article (or portion thereof), which should be paid directly to the Copyright Clearance Center (CCC), 222 Rosewood Drive, Danvers, MA 01923. Payment may also be made electronically through CCC Online at copyright.com. Other copying for republication, resale, advertising or promotion, or any form of systematic or multiple reproduction of any material in this book is prohibited except with permission in writing from the publisher. The CCC fee code is $0277-786 \mathrm{X} / 07 / \$ 18.00$.

Printed in the United States of America.

Publication of record for individual papers is online in the SPIE Digital Library.

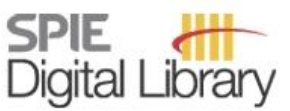

SPIEDigitalLibrary.org

Paper Numbering: Proceedings of SPIE follow an e-First publication model, with papers published first online and then in print and on CD-ROM. Papers are published as they are submitted and meet publication criteria. A unique, consistent, permanent citation identifier (CID) number is assigned to each article at the time of the first publication. Utilization of CIDs allows articles to be fully citable as soon they are published online, and connects the same identifier to all online, print, and electronic versions of the publication. SPIE uses a six-digit CID article numbering system in which:

- The first four digits correspond to the SPIE volume number.

- The last two digits indicate publication order within the volume using a Base 36 numbering system employing both numerals and letters. These two-number sets start with $00,01,02,03,04,05$, 06, 07, 08, 09, OA, OB ... 0Z, followed by 10-1Z, 20-2Z, etc.

The CID number appears on each page of the manuscript. The complete citation is used on the first page, and an abbreviated version on subsequent pages. Numbers in the index correspond to the last two digits of the six-digit CID number. 


\title{
Contents
}

\author{
xi Conference Committee \\ xiii Introduction
}

SESSION 1 REMOTE SENSING AND MODELING THEORY, TECHNIQUES, AND APPLICATIONS I

667902 Remote sensing of vegetation water content using shortwave infrared reflectances (Invited Paper) [6679-01]

E. R. Hunt, Jr., USDA-ARS Hydrology and Remote Sensing Lab. (USA); M. T. Yilmaz, USDA-ARS Hydrology and Remote Sensing Lab. (USA) and George Mason Univ. (USA)

667903 Dependence of erythemally weighted UV radiation on geographical parameters in the United States [6679-02]

X. Wang, W. Gao, J. Davis, B. Olson, G. Janson, J. Slusser, Colorado State Univ. (USA)

667904 Characterization of land cover by multi-temporal biophysical variables in fused images [6679-03]

A. A. López-Caloca, F. Mora, Ctr. de Investigación en Geografía y Geomática (Mexico);

B. Escalante-Ramírez, Univ. Nacional Autónoma de México (Mexico);

A. Miranda-Moctezuma, Ctr. de Investigación en Geografía y Geomática (Mexico)

667905 2-band enhanced vegetation index without a blue band and its application to AVHRR data [6679-04]

Z. Jiang, A. R. Huete, Y. Kim, K. Didan, Univ. of Arizona (USA)

667906 Multisensor reflectance and vegetation index comparisons of Amazon tropical forest phenology with hyperspectral Hyperion data [6679-05]

Y. Kim, A. R. Huete, Z. Jiang, Univ. of Arizona (USA); T. Miura, Univ. of Hawaii (USA)

\section{SESSION 2 REMOTE SENSING AND MODELING THEORY, TECHNIQUES, AND APPLICATIONS II}

667908 Sensitivity analysis of MODIS band-to-band registration characterization and its impact on the science data products [6679-07]

Y. Xie, George Mason Univ. (USA); X. Xiong, NASA Goddard Space Flight Ctr. (USA); J. J. QU, George Mason Univ. (USA) and NASA Goddard Space Flight Ctr. (USA); N. Che, Science Systems and Applications, Inc. (USA); L. Wang, George Mason Univ. (USA)

667909 Vine variety discrimination with airborne imaging spectroscopy [6679-08]

M. Ferreiro-Armán, J. L. Alba-Castro, Univ. de Vigo (Spain); S. Homayouni, J. P. da Costa, LAPS, CNRS, Univ. Bordeaux I (France); J. Martín-Herrero, Univ. de Vigo (Spain)

6679 OA High performance spectrograph for solar UV 250-400 band [6679-09]

I. Di Menno, C. Rafanelli, S. De Simone, M. Di Menno, International Ctr. for Earth Sciences,

CNR, Istituto di Acustica O.M. Corbino (Italy) 
6679 OB Monitoring the intensity of locust damage to vegetation using hyper-spectra data obtained at ground surface [6679-10]

S. Ni, T. Wu, Nanjing Normal Univ. (China)

\section{SESSION $3 \quad$ ECOLOGICAL REMOTE SENSING AND MODELING IN CHINA}

6679 0C A regional climate simulation study with land cover dynamics in Northern China (Invited Paper) [6679-11]

H. Wang, Key Lab. of Regional Climate-Environment Research for Temperate East Asia (China); Y. JU, J. Li, PLA Univ. of Science and Technology (China); G. Qiu, Beijing Normal Univ. (China)

6679 OD Vegetation cover change in semi-arid northeast China using SPOT VEGETATION data [6679-13]

X. Liu, China Univ. of Geosciences (China); F. Huang, P. Wang, Northeast Normal Univ. (China)

6679 OE Wetland dynamics in west Songnen Plain, China since 1950s [6679-14]

F. Huang, P. Wang, Northeast Normal Univ. (China); Y. Zhang, Northeast Institute of Geography and Agricultural Ecology (China)

$66790 G$ Spatial distribution and temporal variation of ultraviolet radiation in Henan Province and the affecting factors [6679-16]

R. Liu, P. Hu, G. Zhao, H. Tian, L. Shi, L. Ye, Henan Institute of Meteorological Sciences (China)

$6679 \mathrm{OH}$ Temporal comparison of land surface albedo for three different land use cover types in the Beijing area [6679-17]

W. Liu, Y. Wang, Institute of Urban Meteorology (China)

6679 Ol Response characteristic analysis of climate change of vegetation activity in Huang-HuaiHai area based on NOAA NDVI data set [6679-18]

Z. Li, Nanjing Univ. of Information Science and Technology (China), Henan Academy of Meteorological Sciences (China), and Inner Mongolian Meteorological Bureau (China);

Z. Sun, Nanjing Univ. of Information Science and Technology (China); H. Chen, Z. Du,

C. Zou, Henan Academy of Meteorological Sciences (China)

6679 OJ Spatial distribution and temporal variation of ecological capital and their relation to climate change and the changes of land use and land cover on the northern slope of the Tianshan Mountain, China [6679-20]

Q. Zhang, X. Chen, Peking Univ. (China); W. Gao, X. Zhang, Colorado State Univ. (USA);

K. Zhou, Xinjiang Institute of Ecology and Geography (China); X. Wang, Colorado State Univ. (USA)

\section{POSTER SESSION}

6679 OK Study on the process of snowmelt based on the 3S technology [6679-21]

S. Fang, Xinjiang Univ. (China); H. Pei, Nanjing Univ. (China); W. Dai, Xinjiang Univ. (China);

Z. Liu, Q. Shi, Xinjiang Univ. (China) and International Ctr. for Desert Affairs (China); Q. Zhao,

Z. LU, M. Li, Y. Yan, Xinjiang Univ. (China) 
$6679 \mathrm{OL}$ Numerical simulation of variance of solar radiation and its influence on wheat growth [6679-22]

X. Zhang, Atmospheric Observation Technical Ctr. of CMA (China) and Nanjing Univ. of Information Science and Technology (China); C. Wang, Chinese Academy of Meteorological Science (China); Z. Du, Henan Institute of Meteorological Science (China): W. Zhai, Chinese Academy of Meteorological Science (China)

6679 OM Spatial and temporal distributions of lightning activities in Northeast China from satellite observation and analysis for lightning fire [6679-23]

J. Zhao, L. Sun, Beiijing Forestry Univ. (China); T. Zhang, Inner Mongolia Agricultural Univ. (Mongolia); D. Zhang, Forest Bureaus in Daxinganling of Inner Mongolia (China); G. Guo, Nanyang Normal Univ. (China); Z. Zhang, Beijing Foresty Univ. (China); Z. Niu, Institute of Remote Sensing Applications (China); X. Kang, Beijing Forestry Univ. (China); H. Liu, INTECS International, Inc. (USA)

6679 ON Influence of land use/cover change on land surface temperature of Laizhou Bay Plain [6679-24]

J. Ning, Shandong Normal Univ. (China) and Institute of Geographic Sciences and Natural Resources Research (China); Z. Gao, Institute of Geographic Sciences and Natural Resources Research (China); Z. Zhang, Z. Li, Shandong Normal Univ. (China)

667900 A remote sensing-based integrated approach for monitoring grassland degradation: case study on the representative grassland near the middle and upper reaches of Heihe River Basin, Western China [6679-25]

Z. Du, Cold and Arid Regions Environmental and Engineering Research Institute (China) and Gansu Agricultural Univ. (China); Y. Shen, Huazhong Agricultural Univ. (China); J. Wang, X. Shen, Cold and Arid Regions Environmental and Engineering Research Institute (China)

Estimate soil organic carbon and nitrogen distribution in Huolin wetland with MODIS data [6679-26]

M. Zhou, Agricultural Univ. of Inner Mongolia (China); G. Z. Wang, USDA Forest Service (USA); G. Guo, Nanyang Normal Univ. (China); L. Heping, USDA Forest Service (USA); L. Wang, Agricultural Univ. of Inner Mongolia (China)

$66790 Q$ Cultivated land changes and driving force analysis by satellite remote sensing in the Yellow River Delta of China [6679-27]

$X$. Zhang, Nanjing Univ. of Information Science and Technology (China) and Taian Meteorological Bureau (China); P. Wang, Nanjing Univ. of Information Science and Technology (China); G. Zhao, Shandong Agricultural Univ. (China); L. Zou, Shanghai Meteorological Bureau (China); G. Lin, J. J. Fletcher, C. Yuill, West Virginia Univ. (USA)

6679 OR A method to compute solar radiation at surface in any time interval based on NCEP re-analysis [6679-28]

L. Zou, Shanghai Meteorological Bureau (China), China Meteorological Administration (China), and Nanjing Univ. of Information Science and Technology (China); W. Gao, Nanjing Univ. of Information Science and Technology (China) and Colorado State Univ. (USA); T. WU, X. XU, China Meteorological Administration (China) 
6679 OS A three-dimensional variational data assimilation system for a climate model: basic scheme and tests [6679-29]

Y. Guan, W. Lu, Nanjing Univ. of Information Science and Technology (China); G. Zhou, Institute of Atmospheric Physics (China); M. Yuan, Provincial Meteorological Observatory of Heilongjiang (China)

6679 OT Analyzing the relationship between land surface temperature and vegetation cover: a case of typical grassland in North China [6679-30]

W. Zhang, Sichuan Univ. (China); Z. Gao, Institute of Geographic Sciences and Natural Resources Research (China)

6679 OU Propagation characters of baroclinic waves in the upper troposphere during the period of rainstorm in Yangtze and Huaihe Valley [6679-31]

S. Mei, Z. Guan, S. Zhong, Nanjing Univ. of Information Science and Technology (China)

$66790 \mathrm{~V}$ The relationship between the intensity of East-Asian summer monsoon in the mid-lower Yangtze Valley and sea surface temperature anomalies in the previous winter [6679-32] $X$. Lu, Institute of Oceanology (China) and Graduate School of the Chinese Academy of Sciences (China); X. Zhang, Beijing Climate Ctr. (China); J. Chen, Institute of Oceanology (China)

6679 0X Preliminary study on the evolution of historical flood/drought features for the northeast of China [6679-34]

N. XU, Provincial Meteorological Bureau of Heilongjiang (China) and Nanjing Univ. of Information Science and Technology (China); P. Guo, Nanjing Univ. of Information Science and Technology (China); M. Yuan, Nanjing Univ. of Information Science and Technology (China) and Provincial Meteorological Observatory of Heilongjiang (China)

6679 OY Analysis of remote sensings of a sudden rainstorm in NE China [6679-35] M. Yuan, Nanjing Univ. of Information Science and Technology (China) and Provincial Meteorological Observatory of Heilongjiang (China); Z. Li, X. Zhang, National Meteorological Ctr. (China)

$66790 Z$ Assessing the impact of climate change on the crop potential productivity in Huang-HuaiHai Plain in China based on crop model and GIS technique [6679-36]

Z. Tian, X. Lei, Shanghai Climate Ctr. (China); Z. Gao, Institute of Geographic Sciences and Natural Resources Research (China)

667910 Temperature change and its effect factors in the Yangtze Delta, China [6679-37]

J. Shi, Shanghai Climate Ctr. (China); X. Tang, Shanghai Meteorological Bureau (China); L. Cui, Shanghai Marine Meteorological Ctr. in Remote Sensing (China); Z. Gao, Institute of Geographic Sciences and Natural Resources Research (China)

667911 Urban heat island in Shanghai, China [6679-38]

L. Cui, Shanghai Marine Meteorological Ctr. in Remote Sensing (China); J. Shi, Shanghai Climate Ctr. (China); Z. Gao, Institute of Geographic Sciences and Natural Resources Research (China) 
667912 Construction of land data assimilation system based on EnKF technology and community land model [6679-39]

Q. Lu, China Meteorological Administration (China); W. Gao, Colorado State Univ. (USA) and International Ctr. for Desert Affairs (China); Z. Gao, Colorado State Univ. (USA), Institute of Geographic Sciences and Natural Resources Research (China), and International Ctr. for Desert Affairs (China); W. Wu, National Ctr. for Atmospheric Research (USA); C. Dong, Z. Yang, P. Zhang, China Meteorological Administration (China); B. Du, Nanjing Univ. of Information Science and Technology (China); J. Slusser, Colorado State Univ. (USA)

667913 Correlations of snow depth retrieved from SSM/I with precipitation and temperature over China [6679-41]

W. Gao, Colorado State Univ. (USA) and International Ctr. for Desert Affairs (China); Q. LU, China Meteorological Administration (China); Z. Gao, Colorado State Univ. (USA), Institute of Geographic Sciences and Natural Resources Research (China), and International Ctr. for Desert Affairs (China); W. WU, National Ctr. for Atmospheric Research (USA); B. Du, Nanjing Univ. of Information Science and Technology (China); J. Slusser, Colorado State Univ. (USA)

667914 Research on Cleistogenes squarrosa's histocytic changing and determine method in the course of restoring succession in degradation community of the typical steppe [6679-42] T. Zhang, Inner Mongolia Agricultural Univ. (Mongolia); W. Wang, Inner Mongolia Univ. (Mongolia); H. Liu, USDA Forest Service (USA); Z. Zhang, Inner Mongolia Agricultural Univ. (Mongolia); C. Liang, L. X. Wang, T. Y. Bu Ren, Inner Mongolia Univ. (Mongolia)

667916 Impact assessment on ecosystem to climate change in Heihe River Basin in NW China [6679-44]

L. Sun, Cold and Arid Regions Environmental and Engineering Research Institute (China) and Lanzhou Regional Climate Ctr. (China); Z. Xu, Cold and Arid Regions Environmental and Engineering Research Institute (China); Z. Ren, Nanjing Information Engineering Univ. (China)

667917 Water quality analysis of Aksu-Tarim River based on remote sensing data [6679-45] J. Ding, Q. Shi, F. Zhang, H. Wang, Xinjiang Univ. (China)

667918 Study on relationship of soil moisture and land cover: a case in Lijin County, Shandong Province [6679-46]

F. Zhang, Institute of Geographic Sciences and Natural Resources Research (China) and Graduate School, Chinese Academy of Sciences (China); Z. Gao, Institute of Geographic Sciences and Natural Resources Research (China); L. Zuo, Graduate School, Chinese Academy of Sciences (China) and Institute of Remote Sensing Applications (China)

667919 Landscape pattern change analyses of land surface radiation during the city expansion in Jinan City [6679-47]

$X$. Zhou, Institute of Geographic Sciences and Natural Resources Research (China) and Graduate School, Chinese Academy of Sciences (China); Z. Gao, Institute of Geographic Sciences and Natural Resources Research (China) 
6679 1A The study of urban sprawl and simulation based on remote sensing and CLUS model [6679-48]

Z. Gao, Institute of Geographic Sciences and Natural Resources Research (China) and Colorado State Univ. (USA); W. Gao, Colorado State Univ. (USA); Z. Jie, Institute of Geographic Sciences and Natural Resources Research (China)

6679 1B The analysis on temporal variation regulation and source of urban aerosol in middle China [6679-49]

D. Chen, China Academy of Meteorological Sciences (China); X. Zhang, Atmospheric Observation Technological Ctr. of CMA (China); W. Deng, Henan Institute of Meteorological Science (China); G. Cao, China Academy of Meteorological Sciences (China); Z. Du, Henan Institute of Meteorological Science (China)

6679 1C EOS/MODIS data-based estimation of the daily snowmelt in Juntanghu Watershed northern slope of Tianshan Mountain [6679-51]

Q. Zhao, Xinjiang Univ. (China); Z. Liu, Q. Shi, Xinjiang Univ. (China) and International Ctr. for Desert Affairs (China); S. Fang, Z. Lu, M. Li, Xinjiang Univ. (China); H. Gong, Urmai Weather Bureau (China)

6679 1D Landscape ecological risk assessment study in arid land [6679-52]

L. Gong, A. Amut, Q. Shi, Xinjiang Univ. (China), International Ctr. for Desert Affairs (China), and Xinjiang Key Lab. of Oasis Ecology (China); G. Z. Wang, USDA Forest Service (USA)

6679 1E Research on spatial differentiation of landscape and ecological construction in arid land oasis [6679-53]

H. Wang, L. Gong, X. Xie, Q. Shi, Z. Liu, Xingjiang Univ. (China), International Ctr. for Desert Affairs (China), and Xinjiang Key Lab. of Oasis Ecology (China)

6679 IF A study of retrieval land surface temperature and evapotranspiration in response to LUCC based on remote sensing data [6679-54]

C. Liu, Nanjing Univ. of Information Science and Technology (China) and Institute of Geographic Sciences and Natural Resources Research (China); W. Gao, Nanjing Univ. of Information Science and Technology (China) and Colorado State Univ. (USA); Z. Gao, Institute of Geographic Sciences and Natural Resources Research (China)

$66791 \mathrm{G}$ The inter-decadal correlation between summer arctic oscillation and summer drought and moist characteristic of northwest China [6679-56]

P. Wang, Nanjing Univ. of Information Science and Technology (China) and Institute of Arid Meteorology (China); Y. Zheng, Nanjing Univ. of Information Science and Technology (China); L. Sun, Institute of Arid Meteorology (China) and Cold and Arid Region Environment and Engineering Research Institute (China); Z. Ren, J. He, Nanjing Univ. of Information Science and Technology (China); Q. Zhang, Institute of Arid Meteorology (China) 
$6679 \mathrm{1H}$ Shiyang River Basin water resources to climate changing respond and to the ecological environmental impact [6679-57]

B. Wang, Lanzhou Institute of Arid Meteorology (China) and Lanzhou Regional Climate Ctr. (China); X. Wang, Lanzhou Institute of Arid Meteorology (China) and Lanzhou Central Meteorological Observatory (China); L. Song, China Meteorological Administration (China); Y. Huang, Lanzhou Institute of Arid Meteorology (China) and Lanzhou Central Meteorological Observatory (China); L. Sun, L. Han, Lanzhou Institute of Arid Meteorology (China) and Lanzhou Regional Climate Ctr. (China)

667911 Land use/land cover change in Yellow River Delta, China during fast development period [6679-59]

W. Zhou, Y. Tian, Southwest Univ. (China); L. Zhu, Chongqing Technology and Business Univ. (China)

$66791 \mathrm{~J}$ On the study of water vapor transport in the Yangtze River Basin under global warming background [6679-60]

Z. Zhang, Nanjing Institute of Geography and Limnology (China), Nanjing Forestry Univ. (China), and Graduate School of the Chinese Academy of Sciences (China); L. Zou, The Chinese Univ. of Hong Kong (Hong Kong China); X.-Z. Liang, Nanjing Univ. of Information Science and Technology (China); T. Jiang, Nanjing Institute of Geography and Limnology (China); J. Zhang, Nanjing Forestry Univ. (China)

6679 iN Validating classification accuracy of low spatial resolution data by using high spatial resolution data [6679-64]

Q. Shi, International Research Ctr. for Sustainable Development in Arid and Semi-Arid Land (China); J. Qi, Michigan State Univ. (USA); L. Chen, National Geomatics Ctr. of China (China); S. Chang, Q. Shi, G. Lv, International Research Ctr. for Sustainable Development in Arid and Semi-Arid Land (China)

667910 Characteristics of spatial distribution and temporal variation of convective cloud merger in Yangtze and Huaihe River Basin in summer season [6679-66]

W. Hu, Y. Huang, L. Wang, Anhui Meteorological Institute (China)

6679 IP Relationship between interdecadal variability of North China summer rainfall, East Asia summer monsoon, and atmospheric circulation anomaly [6679-67]

Q. Gao, Nanjing Univ. of Information Science and Technology (China); L. Hao, Hengshui Meteorological Bureau (China); J. Min, Nanjing Univ. of Information Science and Technology (China); Z. Ren, Chinese Meteorological Administration (China)

$66791 Q$ The benefit valuation method and analytical study of profession meteorological service in China [6679-68]

Z. Ren, Nanjing Univ. of Information Science and Technology (China) and China Meteorological Administration (China); Z. Sun, Nanjing Univ. of Information Science and Technology (China); S. Wang, China Meteorological Administration (China); S. Song, National Meteorological Ctr. (China); B. Wang, China Meteorological Administration (China)

6679 IR The regional climate effects of large-scale agricultural irrigation related to south-to-north water transfer engineering in China [6679-40]

$\mathrm{H}$. Wang, Key Lab. of Regional Climate-Environment Research for Temperate East Asia (China); J. Li, Y. Ju, C. Yang, PLA Univ. of Science and Technology (China) 
6679 is Urbanization patterns and their determinants in Eastern China [6679-12]

L. Zhu, Chongqing Technology and Business Univ. (China); Y. Tian, W. Zhou, Southwest Univ. (China)

6679 1T A comparative study on black carbon aerosol observations in regions of Beijing and Lhasa in 2006 [6679-69]

R. Gao, Nanjing Univ. of Information Science and Technology (China) and Tianjin Meteorological Bureau (China); S. Niu, Nanjing Univ. of Information Science and Technology (China); H. Zhang, China Meteorological Administration (China); J. Guo,

D. Meng, Tianjin Meteorological Bureau (China); J. Ma, Pudong New Area Weather Office (China); J. Feng, Tianjin Meteorological Bureau (China); Y. Zhang, Shandong Meteorological Bureau (China)

$66791 \mathrm{U} \quad$ Warning and controlling of ecological security in Xinjiang, China [6679-70]

G. Lü, Xinjiang Univ. (China), Xinjiang Key Lab. of Oasis Ecology (China), and International Ctr. for Desert Affairs (China); J. Yang, Y. Ma, Q. Shi, Xinjiang Key Lab. of Oasis Ecology (China), Xinjiang Univ. (China), and International Ctr. for Desert Affairs (China); J. Meng, Xinjiang Univ. (China)

$66791 \mathrm{~V}$ Spatial distributions of surface albedo from satellite data in arid oasis [6679-65] A. Amut, L. Gong, Z. Yuan, Xinjiang Univ. (China)

Author Index 


\title{
Conference Committee
}

\author{
Conference Chairs \\ Wei Gao, Colorado State University (USA), Sino-US Cooperative Center \\ for Remote Sensing, Nanjing University of Information Science and \\ Technology (China), and International Center for Desert Affairs \\ (China) \\ Susan L. Ustin, University of California, Davis (USA)
}

Program Committee

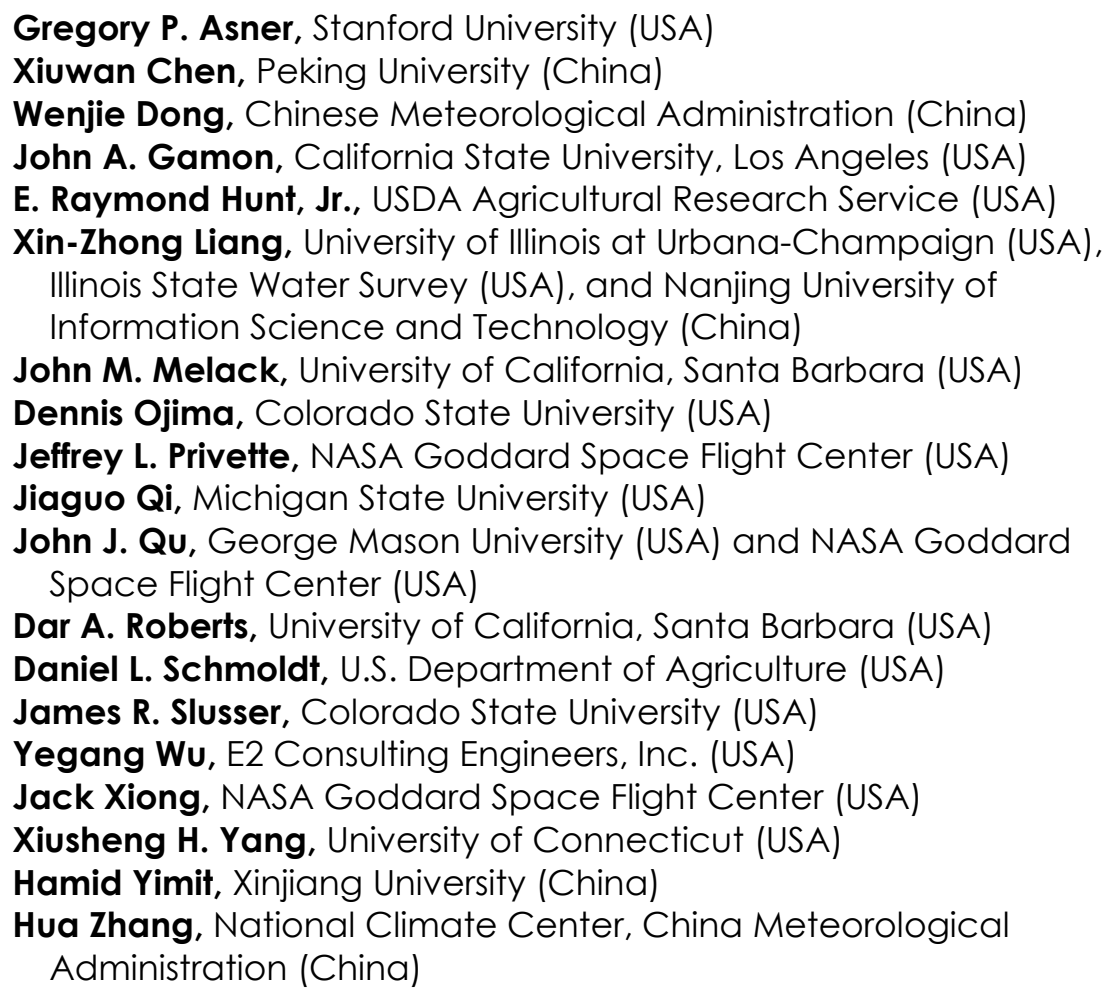

\section{Session Chairs}

1 Remote Sensing and Modeling Theory, Techniques, and Applications I

E. Raymond Hunt, Jr., USDA Agricultural Research Service (USA)

Susan L. Ustin, University of California, Davis (USA) 
2 Remote Sensing and Modeling Theory, Techniques, and Applications II John J. Qu, George Mason University (USA) and NASA Goddard Space Flight Center (USA)

Xinli Wang, Colorado State University (USA)

3 Ecological Remote Sensing and Modeling in China

Hanjie Wang, Key Laboratory of Regional Climate-Environment

Research for Temperate East Asia (China)

Runping Shen, Nanjing University of Information Science and Technology (China)

Huailiang Chen, Henan Institute of Meteorological Sciences (China) 


\section{Introduction}

These proceedings comprise papers presented during the conference on Remote Sensing and Modeling of Ecosystems for Sustainability IV, which was held in San Diego, California, USA, 28-29 August 2007, as part of SPIE's annual international symposium, Optics and Photonics. This conference was designed to focus on ecosystem remote sensing and modeling theory, techniques, and applications. We also held a special session: Ecological Remote Sensing and Modeling in China. More than 70 presentations were delivered in the sessions of oral presentations and poster presentations. This conference provided a great opportunity for scientists from different countries to exchange scientific ideas and discuss their latest research.

Papers were reviewed and edited by conference chairs and conference program committee members, with help from: Drs. Xinli Wang, John Davis, Zhiqiang Gao, and Wanli WU; USDA UV-B supporting staff Rita Deike; and SPIE editorial staff. Special thanks go to the USDA UV-B Monitoring and Research Program and Center of Remote Sensing and Modeling for Agricultural Sustainability, Natural Resource Ecology Laboratory (NREL) at Colorado State University, the International Center for Desert Affairs-Research for Sustainable Development in Arid and Semi-Arid Lands/Urumai, and the Institute of Remote Sensing and GIS, Beijing University, which served as cooperating organizations. The conference owes its success to the diligent efforts of the SPIE technical staff, and Dr. Daniel Schmoldt, Project Manager of USDA/CSREES, for their continued guidance and support.

We would like to extend our appreciation to the outstanding program committee, the session chairs, and especially the authors for their contributions to this successful conference.

Wei Gao

Susan L. Ustin 
Downloaded From: https://www.spiedigitallibrary.org/conference-proceedings-of-spie on 26 Apr 2023

Terms of Use: https://www.spiedigitallibrary.org/terms-of-use 